\title{
Histological and immunohistochemical study on the potential toxicity of sliver nanoparticles on the structure of the spleen in adult male albino rats
}

\section{Original Article}

\author{
Nehad F. Mazen', Ebtehal Z. Saleh', Abeer A. Mahmoud', and Aly A. Shaalan ${ }^{2}$ \\ Department of Histology and Cell Biology, Faculty of Medicine, Zagazig University ${ }^{l}$ and Suez \\ Canal University ${ }^{2}$
}

\begin{abstract}
Introduction: Silver nanoparticles (AgNPs) remain one of the controversial research areas regarding their distribution, dissolution and their toxicity to biological systems.

Aim of the work: To evaluate the potential toxicity of different doses of AgNPs on the spleen of adult Albino rats.

Materials and Methods: Forty adult male albino rats were divided into two main groups; control group: included ten rats that received intraperitoneal saline solution, daily, and experimental group: included thirty rats that received intraperitoneal AgNPs dissolved in saline solution, and were equally subdivided into three subgroups. Subgroup IIa received AgNPs (100 mg/ $\mathrm{kg} / \mathrm{d}$ ), subgroup IIb received AgNPs (500 mg/kg/d) and subgroup IIc received AgNPs (1000 mg/kg/d). After 28 days, rats were euthanized and the spleen specimens were prepared for light and electron microscope studies.

Results: Spleen of AgNPs-treated rats revealed dose-dependent structural changes in the form of reduced sized white pulp follicles with depletion of lymphocytes, degeneration and apoptosis. Nanoparticles were seen in both white and red pulps. There was a highly statistical significant increase in the optical density of caspase-3 in subgroups IIa, IIb and IIc when compared to that of the control group.

Conclusions: AgNPs induced structural alterations in the spleen with evidence of inflammatory response and oxidative stress. These effects were dose-dependent.
\end{abstract}

Key Words: Rat, Silver nanoparticles, spleen, ultrastructure

Revised: 6 January 2017, Accepted: 17 August 2017

Corresponding Author: Nehad Fahmy Mazen, Tel.: 00201010101801, E-mail: nehadmazen@yahoo.com, Department of Histology, Faculty of Medicine, Zagazig University, Sharkia, Egypt

ISSN: 1110-0559, September Vol. 40, No. 3

\section{INTRODUCTION}

Nanoparticles (NPs) are engineered materials produced within the nanoscale range of $1-100 \mathrm{~nm}$, in one or more dimensions ${ }^{[1]}$. They are promising new materials with potential applications in several fields such as therapy, imaging, cosmetics, and food preservation additives. The European Union defined the NPs as natural or manufactured material, present in dispersed or aggregate state and their size usually under $100 \mathrm{~nm}$ in diameter ${ }^{[2]}$. NPs have several characterizations such as small size, high surface area/mass ratio, and surface reactive chemical groups which facilitate their endocytosis by different cells, and interaction with intracellular structures. They have capacity to generate reactive oxygen species (ROS), and to interact with, and potentially disturb the functioning of biomolecules such as proteins, enzymes and $\mathrm{DNA}^{[3,4]}$.

Pure silver has the highest electrical and thermal conductivity of all metals, and low contact resistance. Silver nanoparticles (AgNPs); the best known nanoproducts, have been used in a wide variety of applications due to their unique physical and chemical properties. They have attracted considerable attention as antimicrobial agents, and are effective in retarding growth of bacteria, molds, and harmful spores. Due to their high specific surface area and high proportion of surface atoms, AgNPs have been incorporated into a number of products including clothing, catheters, and electrical home appliances ${ }^{[5]}$.

Engineered AgNPs are used as coatings for hospital beds, medical implants, textiles, wound and burn dressings, as a chemical for water purification, in intragenital contraceptives, and as a disinfectant room spray. They are also used in toothpastes, shampoos, infant nipples, nursing bottles, fabrics, deodorants, filters, kitchen utensils, toys, and humidifiers ${ }^{[6]}$. These broad applications, however, increase human exposure and thus the potential risk related to their short- and long-term toxicity ${ }^{[7]}$. The health effects of this material have not been well characterized even though the toxicity of nanosilver has been demonstrated in vitro models ${ }^{[8]}$.

More importantly is the potential for the application of AgNPs in the treatment of diseases that require maintenance of circulating drug concentration or targeting of specific 
cells or organs. For example, AgNPs have been shown to interact with the HIV-1 virus and inhibit its ability to bind host cells in vitro. Despite their widespread application, comprehensive biologic and toxicological information is lacking. In addition, exposure and associated risk to human and environmental health have not been explored systematically ${ }^{[9]}$. A large number of in vitro studies indicate that Ag NPs are toxic to the mammalian cells derived from skin, liver, lung, brain, vascular system and reproductive organs. Interestingly, some studies have shown that these particles have the potential to induce genes associated with cell cycle progression, DNA damage and apoptosis in human cells at non-cytotoxic doses ${ }^{[10]}$.

AgNPs can enter the human gastrointestinal tract by several routes, including air, water, food, soil, cosmetics, drugs, and drug delivery devices and can be distributed throughout the body via the circulatory system. However, excessive use of nanoparticles may be hazardous to human health and the environment and can lead to a wide variety of toxicological effects. Nanoparticles are more likely to travel through organs than larger particles, and can produce adverse affects on several organs ${ }^{[11]}$.

Therefore, we aimed in this study to assess the potential toxicity of different doses of AgNPs on the structure of the spleen of adult male albino rats, and to clarify the possible underlying mechanisms.

\section{MATERIALS AND METHODS}

\section{Animals}

Forty healthy adult male albino rats (5-7 months) with an average body weight ranging from 200-250 g were utilized in this study. The rats were obtained from the animal house of the Faculty of Medicine, Zagazig University, Zagazig, Egypt. The animals were kept under strict hygienic laboratory conditions; $12 \mathrm{~h}$ dark and $12 \mathrm{~h}$ light cycle. They were housed at room temperature, fed standard balanced diet and allowed water ad libitum. All animals were housed according to the guidelines for animal research issued by the National Institute of Health ${ }^{[12]}$, and approved by Animal Ethics Committee, Zagazig University.

\section{Chemicals}

1. Silver nanopowder with a particle size less than $100 \mathrm{~nm}$ and a $99.9 \%$ trace metals basis was purchased from Sigma-Aldrich Chemicals, Cairo, Egypt.

2. Anti-caspase 3 antibodies, (Novacastra Laboratories Ltd, UK) were purchased from Sigma office (Egyptian International Center for Import, Cairo, Egypt).

3. Mayer's hematoxylin (Sigma-Aldrich Chemie, Steinheim, Germany) were purchased from Algomhuria Co. (Mohafza st., Zagazig, Egypt)

\section{Visualization of nanoparticles}

To study the morphology and the particle size of the nanoparticles, AgNPs have been dissolved in $0.5 \%$ aqueous carboxymethylcellulose (Sigma-Aldrich). The aqueous dispersion of the nanoparticles was dropped onto carboncoated copper grids (200 mesh). The grids were air-dried at room temperature and visualized using a transmission electron microscope (TEM) operating at $80 \mathrm{kV}$, and the diameter was determined from the micrographs ${ }^{[13,14]}$.

\section{Experimental procedure}

After two weeks of acclimatization, the animals were divided into two main groups:

Group I (Control group): Included ten rats that received saline solution by intraperitoneal injection (IP), daily for 28 days.

Group II (Experimental group): Included thirty rats that received IP AgNPs (dissolved in saline solution) daily for 28 days. They were equally subdivided into three subgroups each received a specific dose of $\mathrm{AgNPS}^{[15]}$ :

Subgroup IIa received AgNPs at a dose of $100 \mathrm{mg} / \mathrm{kg}$.

Subgroup IIb received AgNPs at a dose of $500 \mathrm{mg} / \mathrm{kg}$.

Subgroup IIc received AgNPs at a dose of $1000 \mathrm{mg} / \mathrm{kg}$.

AgNPs in the injected doses were distributed more uniformly by sonication for 10 minutes just before injection, to be taken by systemic circulation ${ }^{[14]}$.

\section{Toxicological assessment of nanosilver}

During the time of dosing (28 days), all the experimental rats were inspected for clinical signs of toxicity including emotion (excitability, aggressiveness), autonomous functions (diarrhoea, diuresis, and salivation) and also mortality.

\section{Histological study}

After 28 days, rats from all groups were sacrificed and their spleens were carefully dissected out and prepared for light and electron microscopic studies at Histology and cell Biology Department, Faculty of medicine, Zagazig university. Specimens for light microscope were fixed in $10 \%$ buffered formalin, and processed to prepare $5 \mu \mathrm{m}$ thick sections to be stained with haematoxylin and eosin stains, and immunohistochemical stain for detection of caspase- $3^{[16]}$.

For immunohistochemical analysis [Biovision activated Caspase-3 (1:100)], paraffin sections were deparaffinized in xylene, rehydrated and washed in phosphate buffer solution (PBS). Sections were treated with 3\% hydrogen peroxide and washed with PBS. The primary antibody was applied and washed with PBS. The biotinylated secondary 
antibody was applied, washed with PBS before incubating with the enzyme conjugate and 3,3-diaminobenzidine tetrahydrochloride (DAB). Sections were counterstained with Mayer's hematoxylin. Negative controls were prepared by omitting the primary antiserum incubation ${ }^{[16]}$ while positive controls were from normal human palatine tonsils.

For electron microscopic study, small pieces $\left(1 \mathrm{~mm}^{3}\right)$ of the spleen were fixed in $2.5 \%$ glutaraldehyde buffered with $0.1 \mathrm{M}$ phosphate buffer at $\mathrm{pH} 7.4$ for $2 \mathrm{~h}$ at $4^{\circ} \mathrm{C}$, post-fixed in $1 \%$ osmium tetroxide, dehydrated with ascending grades of ethanol, and embedded in epoxy resin ${ }^{[17]}$. Semithin sections were stained with toluidine blue to be examined with light microscope ${ }^{[18]}$. Ultrathin sections were stained with uranyl acetate and lead citrate ${ }^{[19]}$ and examined with JEOL transmission electron microscope [JEM-100CXII, JEOL Ltd., Tokyo, Japan], Al-Azhar University, Egypt.

\section{Morphometric analysis}

Measurement of the optical density of caspase-3 reaction was done using "Leica Qwin 500" image analyzer computer system (Leica imaging system LtD, Cambridge, England) in Pathology Department, Faculty of Dentistry, Cairo University, Cairo, Egypt. The measurements were obtained in non-overlapping ten fields in slides of five different rats in each group at X400 magnification.

\section{Statistical Analysis}

Data were expressed as mean \pm standard deviation $(\mathrm{X} \pm \mathrm{SD})$. Data obtained from the image analyzer were subjected to SPSS program version 15. Statistical significant difference was determined by one way analysis of variance (ANOVA), followed by least significant difference (LSD) Post hoc test for multiple comparison between different groups. The probability value $P<0.05$ was considered significant.

\section{RESULTS}

\section{Animal symptoms, food consumption, and general}

\section{activity}

No mortality, gross effects, or significant difference in food consumption or body weight were observed during the study period in any of the rats administered AgNPs when compared with the control group. However, treated rats showed a marked decrease in activity.

\section{Nanoparticles' characterization:}

TEM imaging of AgNPs ranging from $20 \mathrm{~nm}$ to $80 \mathrm{~nm}$ in diameter was performed to confirm primary particle size and general morphology. Aggregations of AgNPs in the size ranging of $47-80 \mathrm{~nm}$ were seen. However, smaller nanomolecules (less than $30 \mathrm{~nm}$ ) appeared to exist as solitary entities (Fig. I).

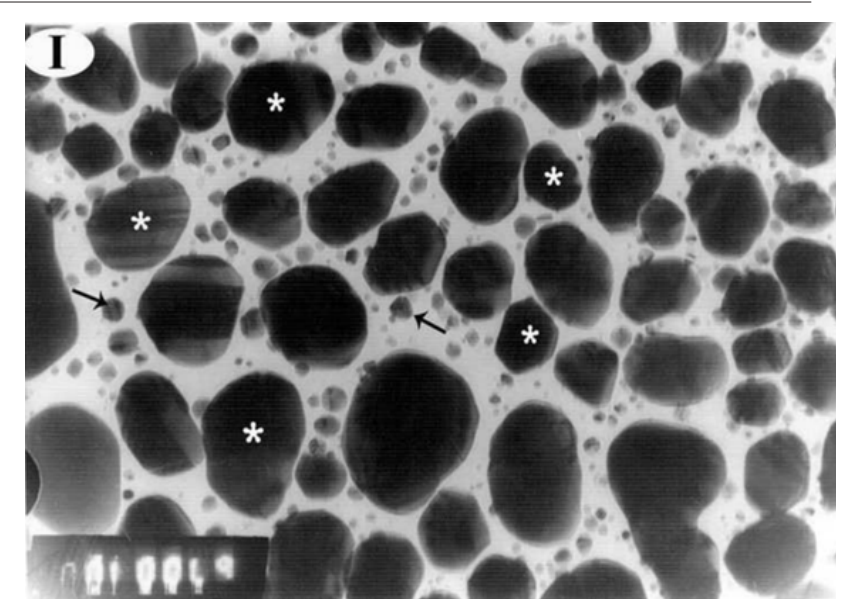

Fig. I: An electron micrograph showing aggregations of AgNPs in the size range of $47-80 \mathrm{~nm}$ (asterisk) were seen. However, smaller nanomolecules (less than $30 \mathrm{~nm}$ ) (arrow) appear to exist as solitary entities.

(TEM, Mic. Mag. X67.000).

\section{Histological results}

\section{Light microscopic results:}

Examination of $\mathrm{H} \&$ E-stained sections of the control group revealed normal spleen architecture with its two major components; white pulps and red pulp, separated by marginal zones. The white pulp consisted of follicle with pale germinal center and a peripherally-located central arteriole, surrounded by a sheath of lymphocytes; periarterial lymphatic sheath. The red pulp was composed of splenic sinuses and cords of Billroth. Macrophages were identified by particles they have sequestered (Figs. 1 and 2). In subgroup IIa, the white pulp revealed some vacuolated cells, indicating degeneration. The red pulp contained congested splenic sinuses. Nanoparticles were seen in both white and red pulps (Figs. 3 and 4). In subgroup IIb, the white pulps of the spleen appeared reduced in size and contained vacuolated cells with fragmented nuclei, indicating apoptosis (Figs. 5 and 6). Furthermore, subgroup IIc showed white pulp follicles which were reduced in size with depletion of lymphocytes, and indistinct marginal zones. The red pulp revealed different lineages of haemopoiesis mainly those of erythropoiesis and thrombopoiesis. Erythropoiesis was represented by series of basophilic cell aggregations, while thrombopoiesis was represented by series of megakaryocytes with their multilobed nuclei, and megakaryoblasts with their small and less lobulated nuclei. There was also widening of the splenic sinuses, indicating congestion of the spleen. Nanoparticles were also observed in both white and red pulps (Figs. 7and 8).

Immunolocalization of caspase 3 revealed negative reaction in the spleen of the control group (Fig. 9). In subgroup IIa, there was cytoplasmic reaction in some splenocytes of both red and white pulps (Fig. 10) while 
in subgroup IIb, strong cytoplasmic reaction were seen in splenocytes of both red and white pulps (Fig. 11). However, subgroup IIc showed extensive cytoplasmic in splenocytes of both red and white pulps (Fig. 12).

\section{Electron microscopic results}

Ultrastructurally, the white pulp of the control spleen revealed blood vessels lined with endothelial cells and surrounded by lymphocytes of different sizes. These lymphocytes had nuclei with homogenously distributed chromatin. Macrophages were large and extend their process between lymphocytes. Reticular cells were seen peripheral to lymphocytes (Fig. 13). The red pulp contained lymphocytes, macrophages and splenic sinuses that were lined with elongated endothelial cells and filled with RBCs (Fig. 14).

Concerning subgroup IIa, the white pulp showed lymphocytes with different grades of marginal condensed chromatin in their nuclei, and cytoplasmic vacuoles. Lymphoblasts, reticular cells and reticular fibers were also seen (Fig. 15). The red pulp revealed lymphocytes, and blood sinuses with their endothelial lining and their content of RBCs and neutrophils. Nanoparticles were also seen (Fig. 16).

In addition, the white pulps of the spleens in subgroup $\mathrm{IIb}$ showed lymphocytes with different grades of marginal condensed chromatin in their nuclei, pyknotic nuclei, apoptotic bodies, mitotic figures and cytoplasmic vacuoles. Reticular cells and macrophages were also seen (Figs. 17 and 18). The red pulp contained lymphocytes with different grades of condensed chromatin in their nuclei, active macrophages engulfing RBCs or AgNPs, reticular cells, and RBCs (Figs. 19 and 20).

In subgroup IIc, the white pulps of spleens had active macrophages with multiple phagosomes, lymphocytes with apoptotic nuclei and dark cytoplasm, and reticular cells. Most of these cells contained dilated rough endoplasmic reticulum (Figs. 21 and 22). The red pulps revealed splenic sinuses crowded with RBCs, and macrophages engulfing silver nanoparticles (Fig. 23).

\section{Morphometric results}

There were high statistical significant differences between control and other groups regarding optical density of caspase-3. There was significant increase in group IIa, IIb and IIc than the control group $(p<0.001)$. The comparison among different groups of the study by LSD test; group IIa, group IIb and group IIc showed a highly statistical significant increase in the mean value of caspase-3 optical density $(2.493 \pm 0.0096),(2.542 \pm 0.015)$ and $(2.564 \pm 0.0239)$, respectively when compared to those of control group $(p<0.001)$. Also, group IIb and group IIc showed a highly statistical significant increase when compared to those of group IIa $(p<0.001)$. There was a significant increase in group IIc compared to group IIb $(2.564 \pm 0.0239)(p<0.05)$ (Table. 1$)$.

Table (1): Comparison between mean values of the optical density of caspase-3 in the different studied groups using ANOVA (analysis of variance) and Least significant difference (LSD) post hoc test.

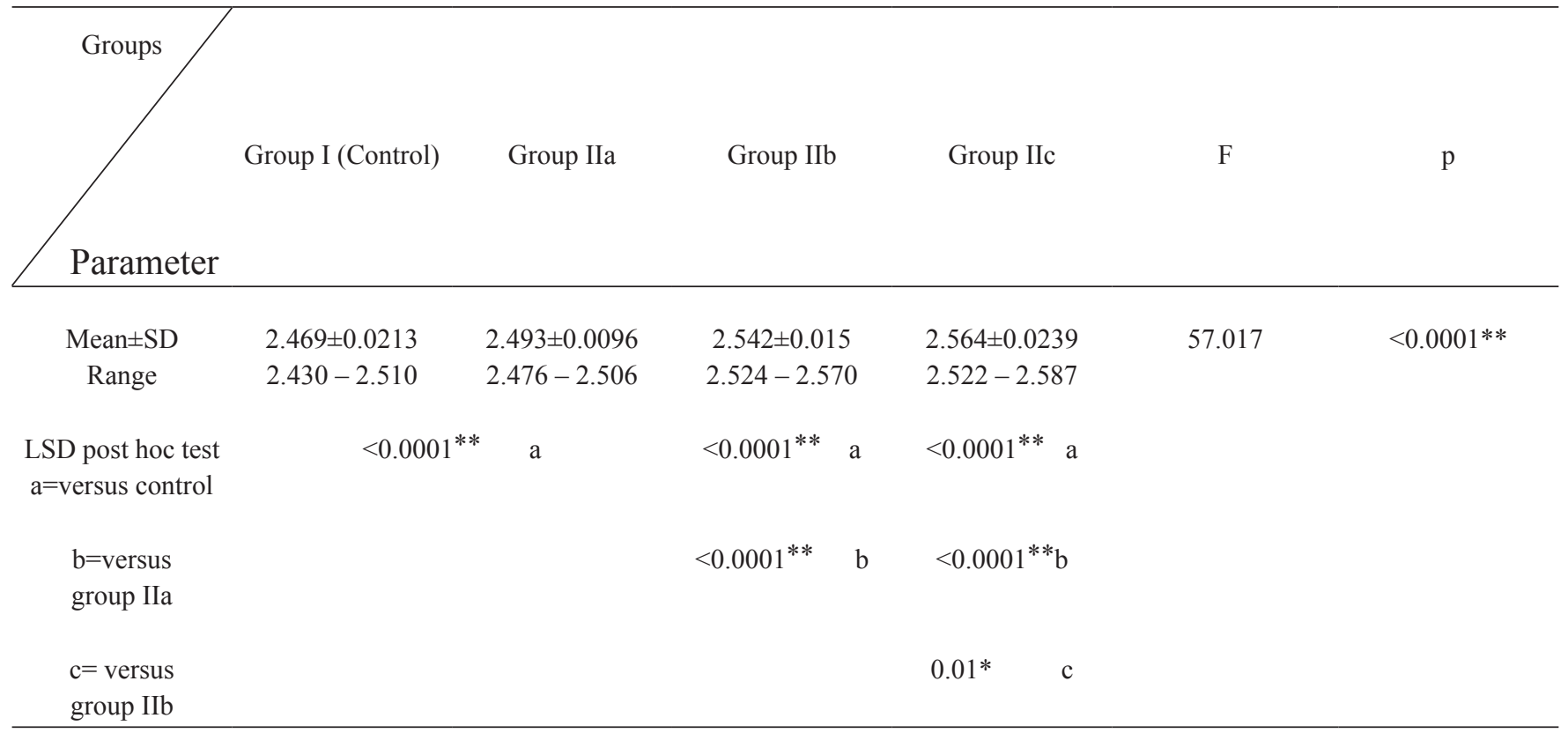

Number of sacrificed rats for each group was 10 rats.

SD: Standard Deviation.

$*$ : significant $(p<0.05)$

$* *$ : highly significant $(p<0.001)$ 


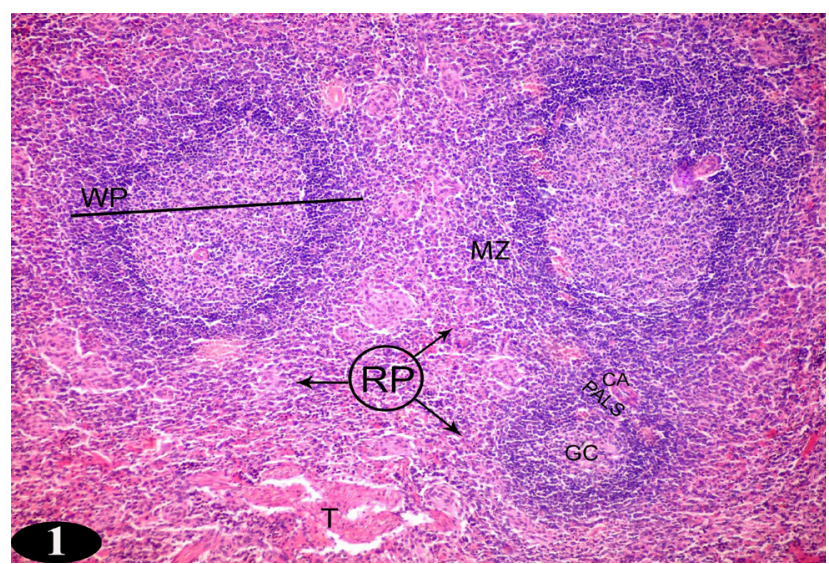

Fig. 1: A photomicrograph of a section in a control rat spleen showing normal spleen architecture with its two major components; white pulp (WP) and red pulp (RP), separated by marginal zone (MZ). The white pulp has follicle with pale germinal center (GC) and a peripherally located central arteriole (CA), surrounded by periarterial lymphatic sheath (PALS). A part of a fibrous trabecula $(\mathrm{T})$ is also seen.

(H\&E, X 100).

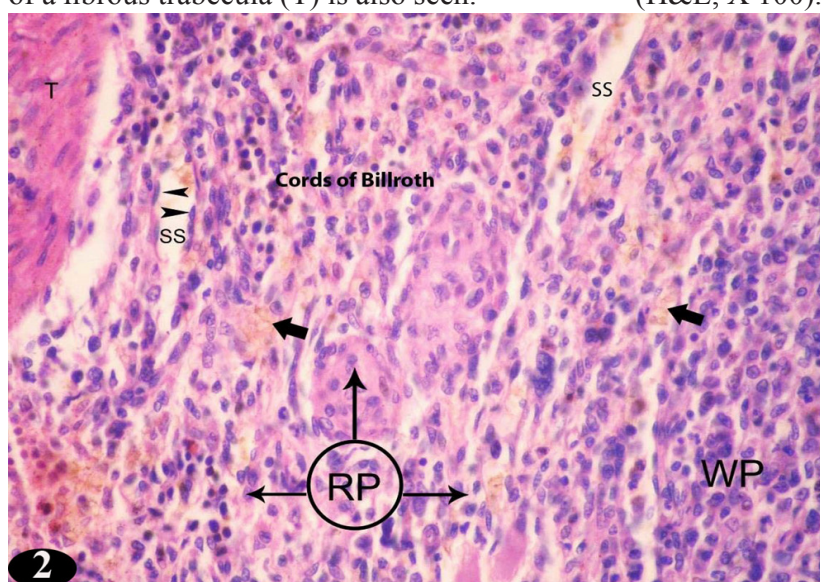

Fig. 2: A photomicrograph of a section in a control rat spleen showing white (WP) and red (RP) pulps. The red pulp contains splenic sinuses (ss) and cords of Billroth in between. The sinuses are lined with endothelial cells (arrowheads). Macrophages are identified by particles they have sequestered (thick arrow). A part of the fibrous trabecula (T) is also seen. (H\&E, X 400).

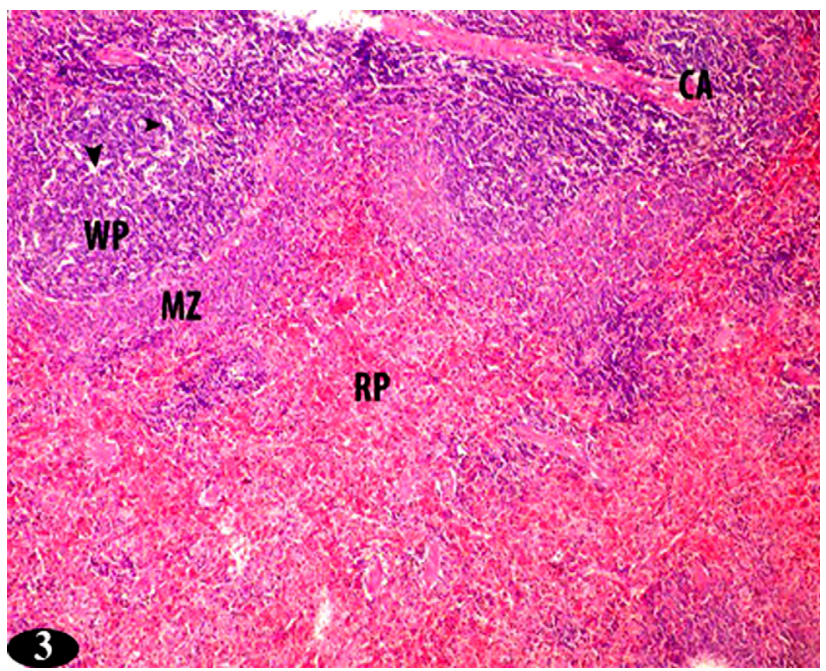

Fig. 3: A photomicrograph of a section in a rat spleen from subgroup IIa (after interaperitoneal injection with NPs $100 \mathrm{mg}$ / $\mathrm{kg}$ ) showing white pulp (WP) and red pulp (RP). Many cells in the white pulp appear vacuolated (arrowheads). Note, central artery (CA) and marginal zone (MZ) are seen. (H\&E, X 100).

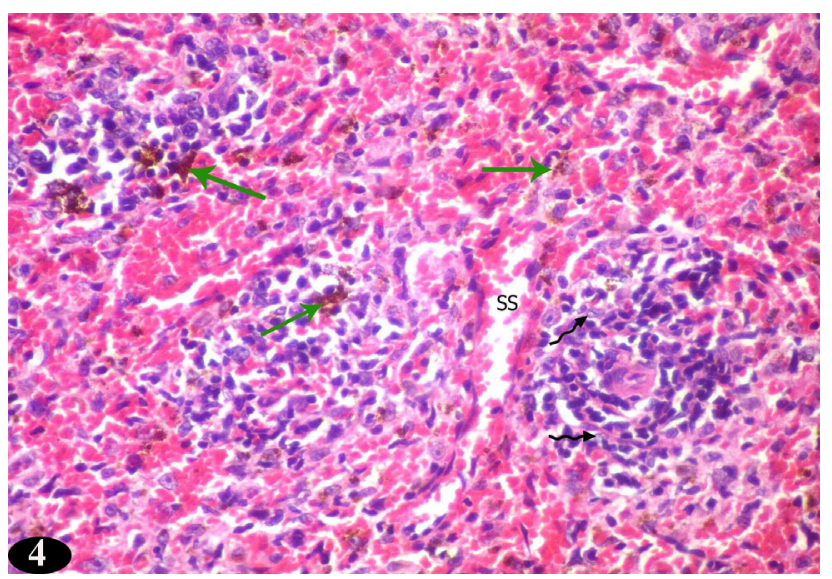

Fig. 4: A photomicrograph of a section in a rat spleen from subgroup IIa (after interaperitoneal injection with NPs $100 \mathrm{mg} / \mathrm{kg}$ ) showing some vacuolated cells (wavy arrow) in the white pulp. The red pulp contains congested splenic sinuses (ss) Nanoparticles (green arrows) are seen in both white and red pulps.

(H\&E, X 400)

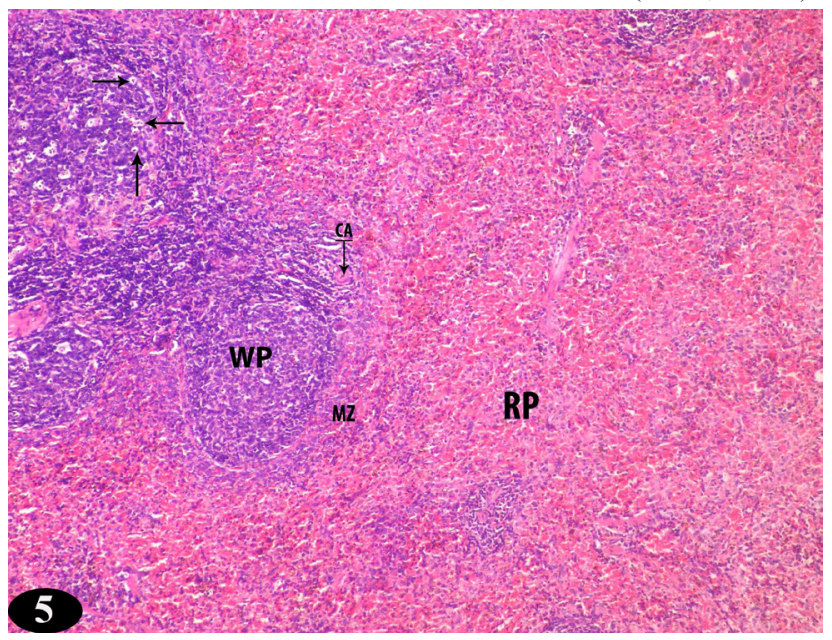

Fig. 5: A photomicrograph of a section in a rat spleen from subgroup IIb (after interaperitoneal injection with NPs $500 \mathrm{mg}$ / $\mathrm{kg}$ ) showing reduced size of white pulp (WP) in relation to the red pulp (RP). Many cells in the white pulp appear vacuolated (arrows). Note, central artery (CA) and marginal zone (MZ) are seen.

(H\&E, X 100)

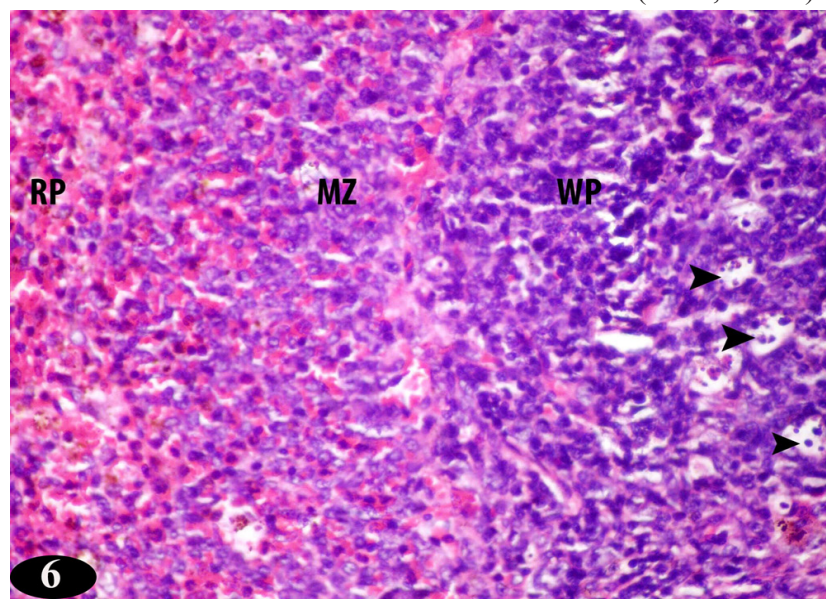

Fig. 6: A photomicrograph of a section in a rat spleen from subgroup IIb (after interaperitoneal injection with NPs 500 $\mathrm{mg} / \mathrm{kg}$ ), showing white pulp (WP), red pulp (RP) and marginal zone (MZ). Many cells in the white pulp appear vacuolated with fragmented nuclei (arrowheads) indicating apoptosis.

(H\&E, X 400) 


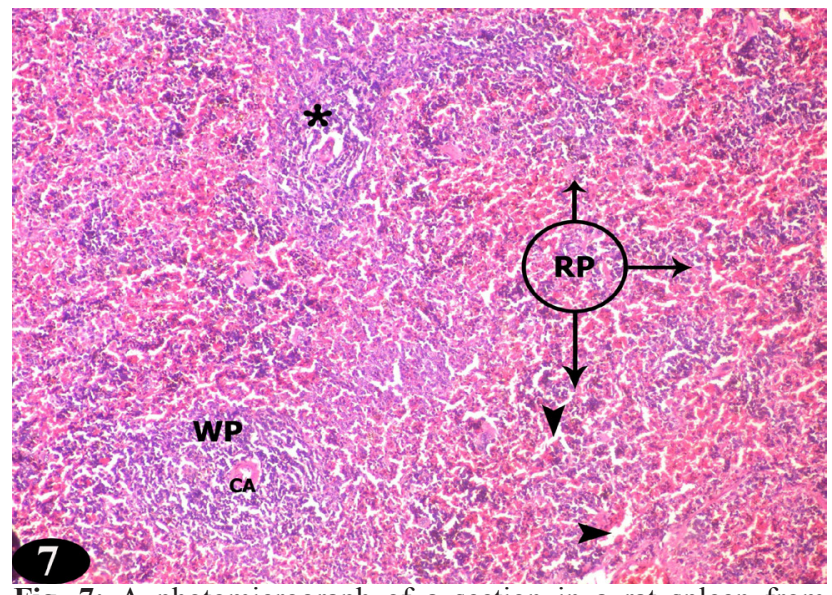

Fig. 7: A photomicrograph of a section in a rat spleen from subgroup IIc (after interaperitoneal injection with NPs $1000 \mathrm{mg}$ / $\mathrm{kg}$ ), showing white pulp follicles (WP) which appear reduced in size (asterisk) with depletion of lymphocytes. The red pulp (RP) has widened sinuses (arrowheads). The marginal zone is indistinct. Note, central artery (CA) is also seen. (H\&E X 100).

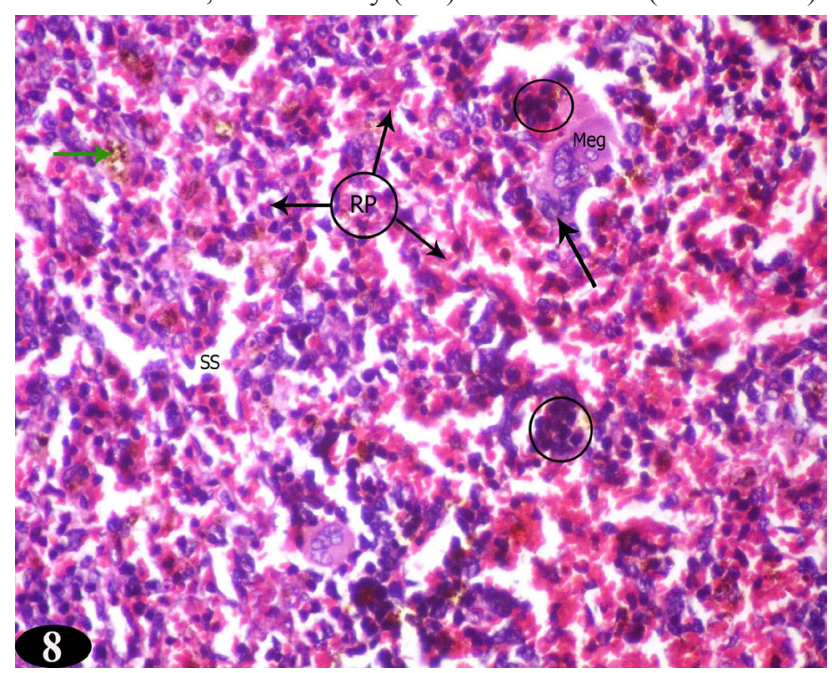

Fig. 8: A photomicrograph of a section in a rat spleen from subgroup IIc showing red pulp (RP) with two lineages of hematopoietic elements: erythropoiesis (circle) that contains basophilic darkly stained cells, and thrombopoiesis that has megakaryocytes (Meg) with their lobulated nuclei, and megakaryoblasts (arrow) with their small and less lobulated nuclei. Splenic sinuses (SS) are widened. Nanoparticles (green arrow) are also seen in both white and red pulps.

(H\&E X 400).

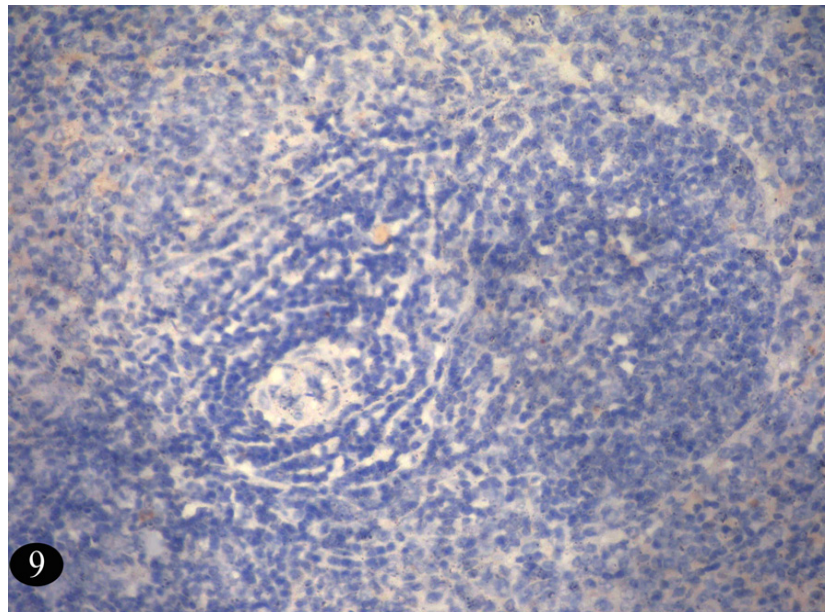

Fig. 9: A photomicrograph of a section in a control rat spleen showing negative reaction to caspase-3 in splenocytes of both red and white pulps.
(Immunoperoxidase X400).

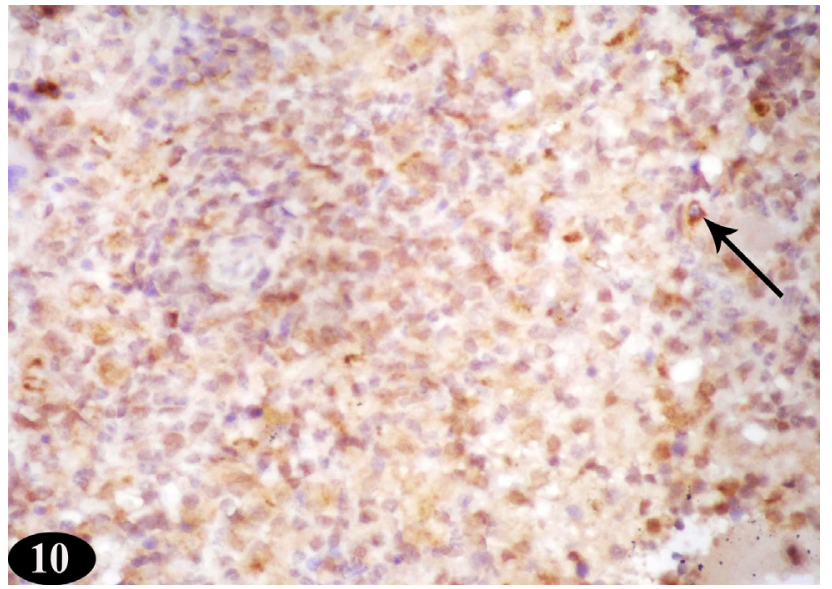

Fig. 10: A photomicrograph of a section in a rat spleen from subgroup IIa (after interaperitoneal injection with NPs $100 \mathrm{mg} / \mathrm{kg}$ ) showing cytoplasmic reaction to caspase-3 (arrow) in some splenocytes of both red and white pulps (Immunoperoxidase X400).

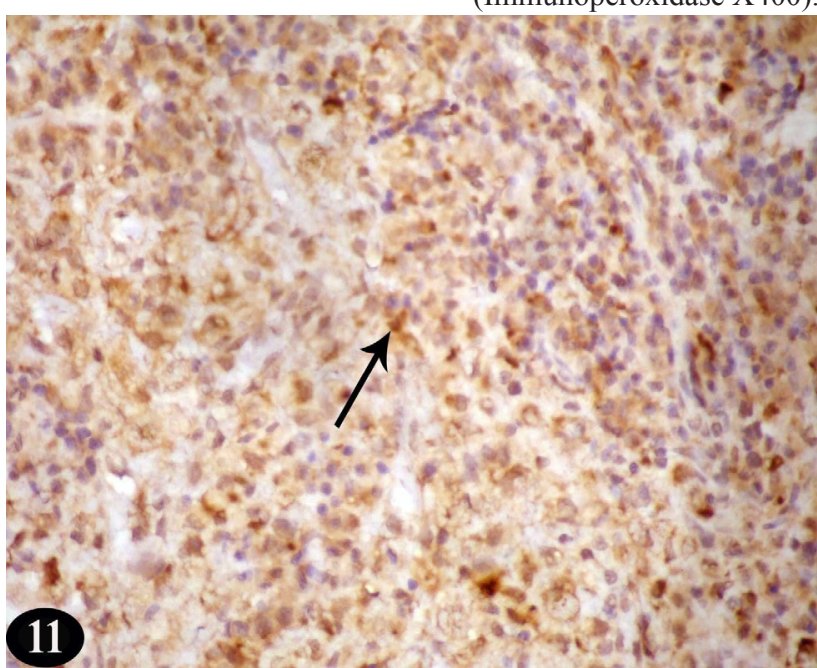

Fig. 11: A photomicrograph of a section in a rat spleen from subgroup IIb (after interaperitoneal injection with NPs $500 \mathrm{mg} / \mathrm{kg}$ ) showing strong cytoplasmic reaction to caspase-3 (arrow) in splenocytes of both red and white pulps. (Immunoperoxidase X400)

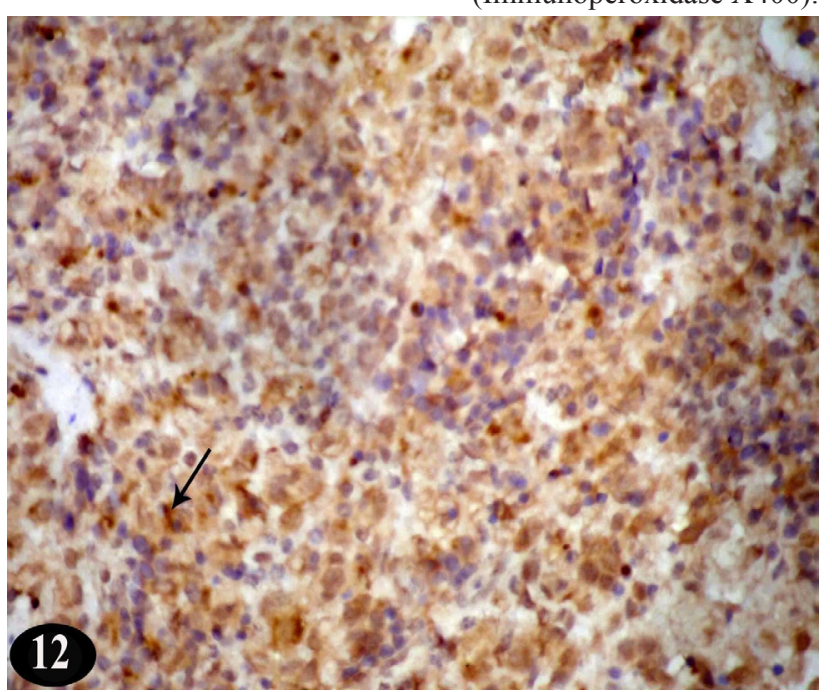

Fig. 12: A photomicrograph of a section in a rat spleen from subgroup IIc (after interaperitoneal injection with NPs 1000 $\mathrm{mg} / \mathrm{kg}$ ), showing extensive cytoplasmic reaction to caspase-3 (arrow) reaction in splenocytes of both red and white pulps. (Immunoperoxidase X400). 


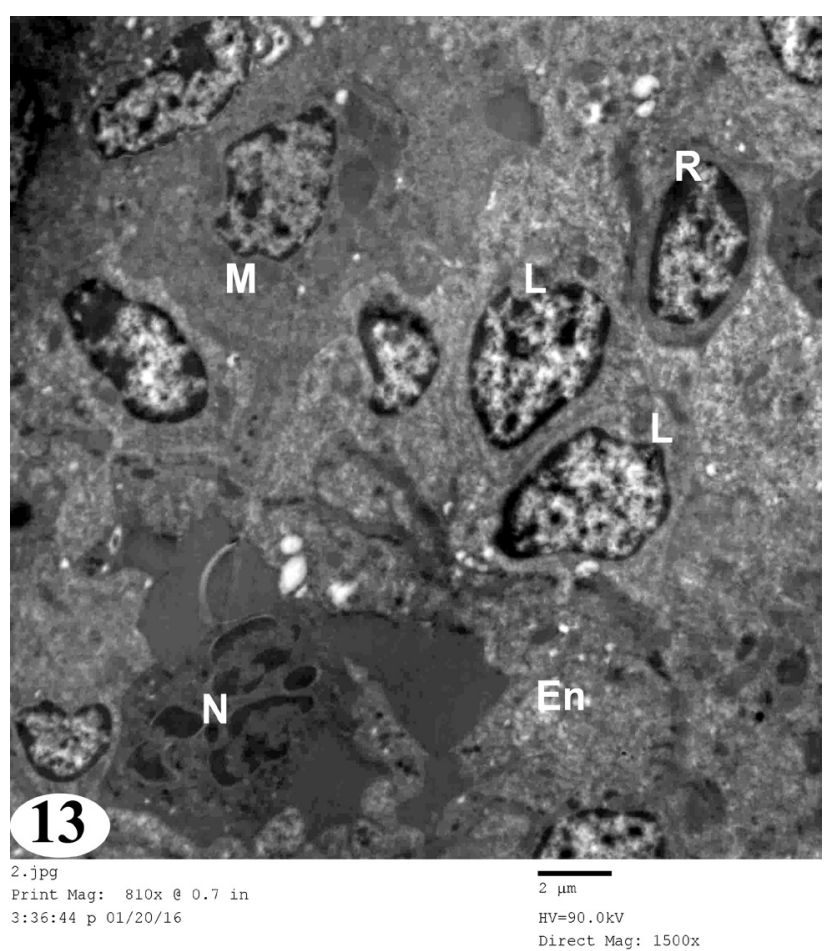

Fig. 13: An electron micrograph of a rat spleen from the control group showing the cellular components of the white pulp that has a blood vessel lined with endothelial cells (En) and contains a neutrophil cell $(\mathrm{N})$. Lymphocytes (L) appear to surround the blood vessel. The nuclei of lymphocytes have homogenously distributed chromatin. Macrophage (M) cell is large and extend its processes between lymphocytes. Reticular cell (R) is present peripheral to lymphocytes. (TEM, X1500).

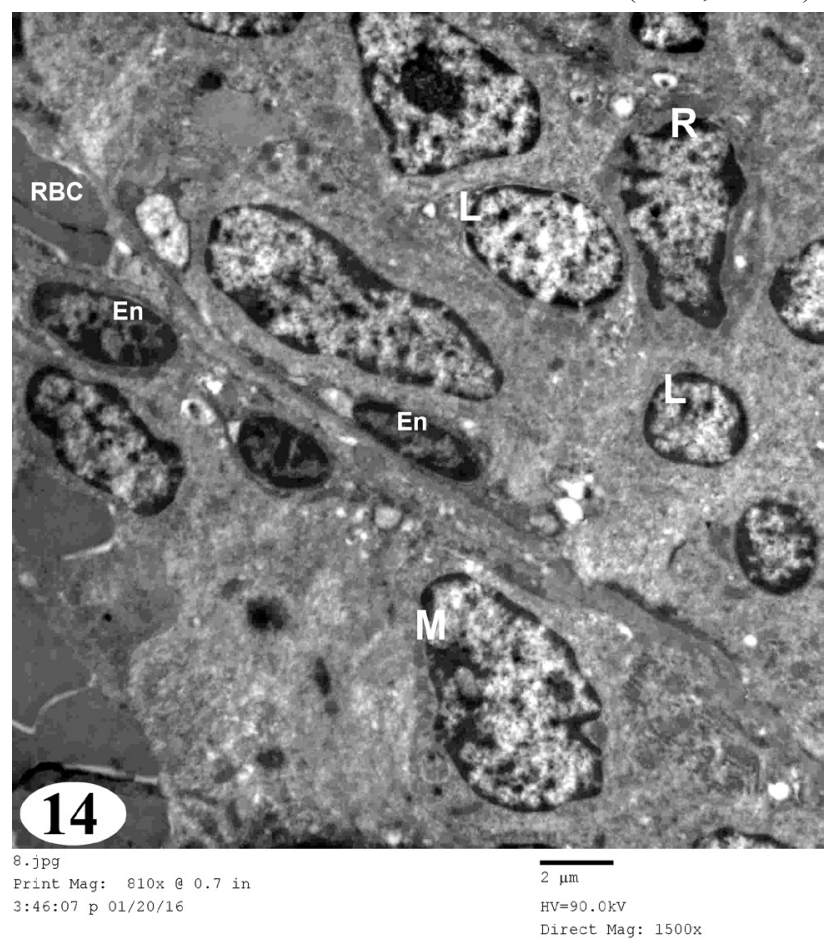

Fig. 14: An electron micrograph a rat spleen from the control group showing the cellular components of the white and red pulps. The white pulp contains lymphocytes (L) and reticular cells (R) while the red pulp contains macrophage (M) and splenic sinus that is lined with elongated endothelial cells (En) and filled with red blood corpuscles (RBC). (TEM, X1500).

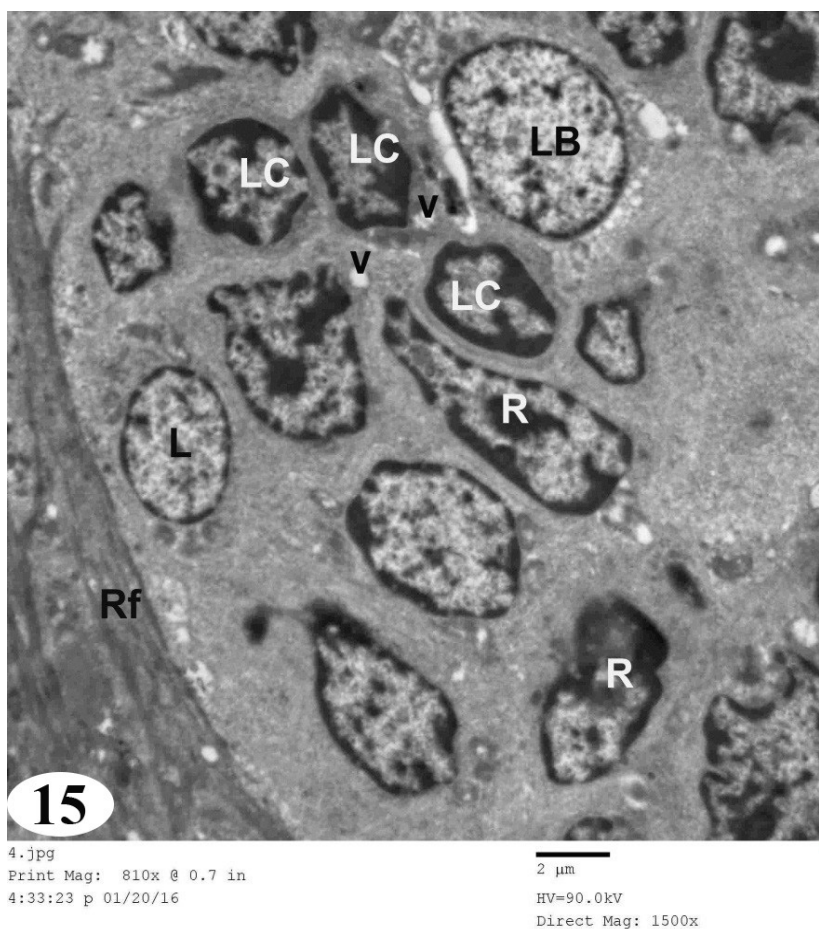

Fig. 15: An electron micrograph a rat spleen from subgroup IIa showing the cellular components of the white pulp. Some lymphocytes (L) appear with normal chromatin distribution in their nuclei and others with marginal condensed chromatin (LC). A lymphoblast (LB) and reticular cells (R) also appear. Reticular fibers (Rf) are seen at the periphery of the white pulp. Some cells show vacuolations (v)

(TEM, X1500)

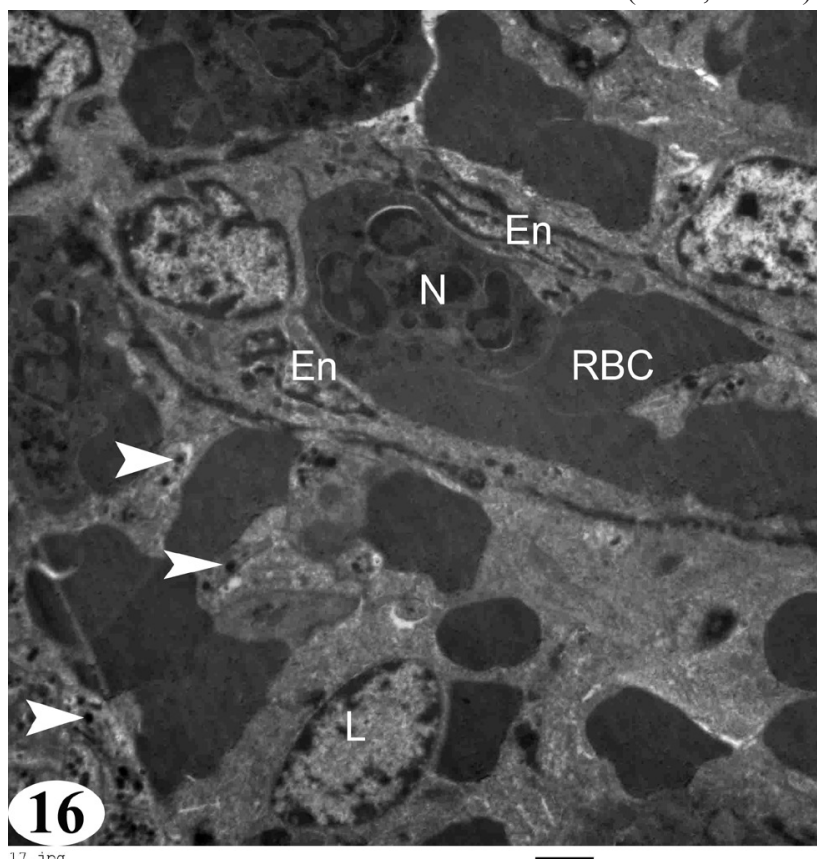

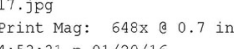

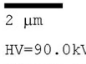

Fig. 16: An electron micrograph of a rat spleen from subgroup IIa showing the cellular components of the red pulp including lymphocytes (L), a blood sinus lined with endothelial cell (En) and containing neutrophils (N), and red blood corpuscles (RBC).

Nanoparticles (arrowheads) are also seen.

(TEM, X1200). 


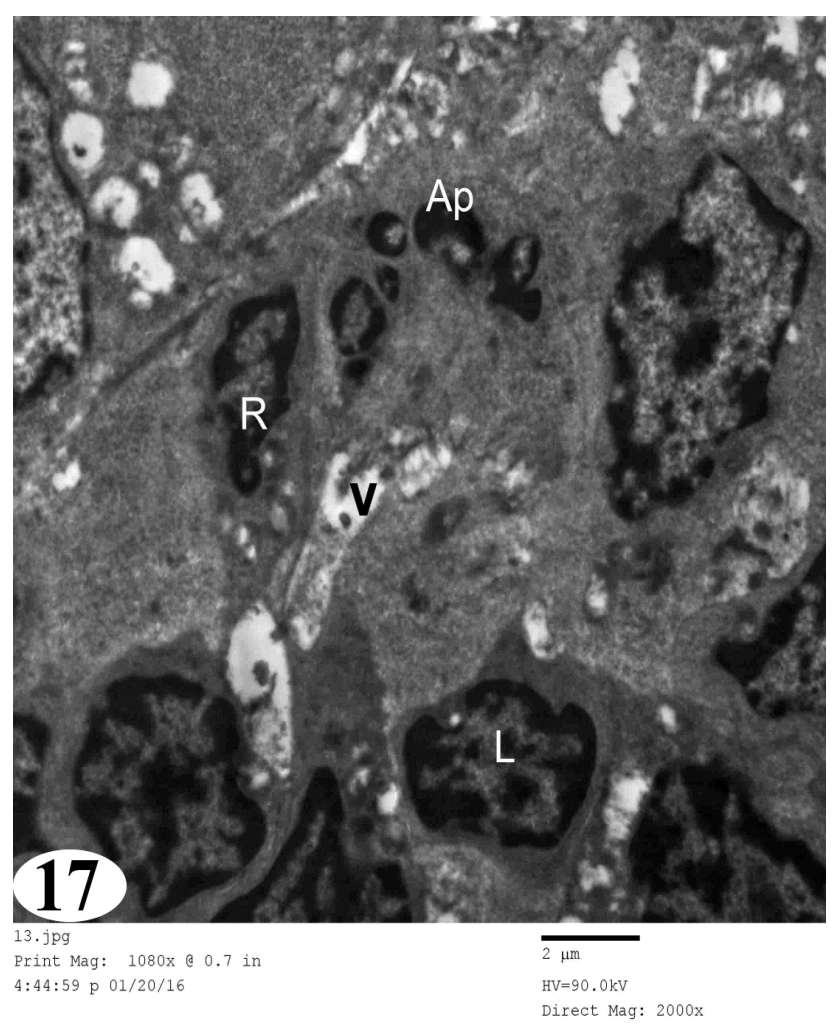

Fig. 17: An electron micrograph of a rat spleen from subgroup IIb showing the cellular components of the white pulp including lymphocytes (L) with different grades of marginal condensed chromatin in their nuclei, and reticular cells (R). Some cells reveal apoptotic bodies (Ap) and cytoplasmic vacuoles (v). (TEM, X2000).

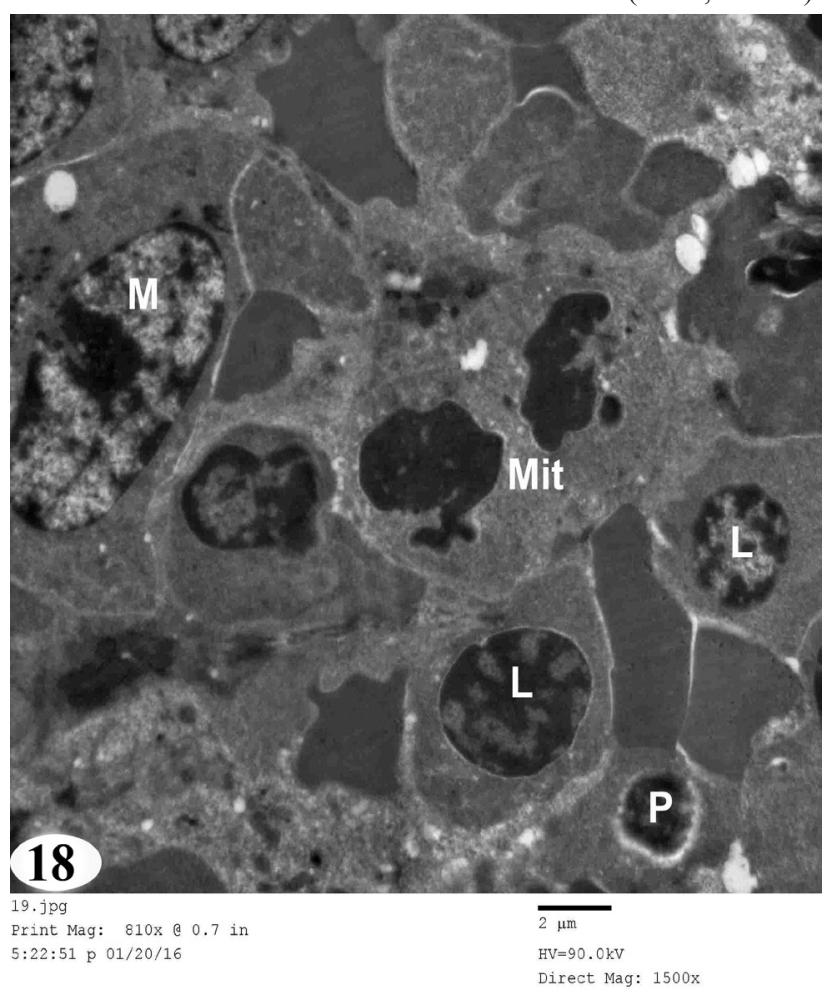

Fig. 18: An electron micrograph of a rat spleen from subgroup IIb showing the cellular components of the white pulp; lymphocytes (L) with different grades of marginal condensed chromatin in their nuclei. Some lymphocytes (p) have pyknotic nuclei while others undergo mitosis (Mit). A macrophage (M) is also seen. (TEM, X1500).

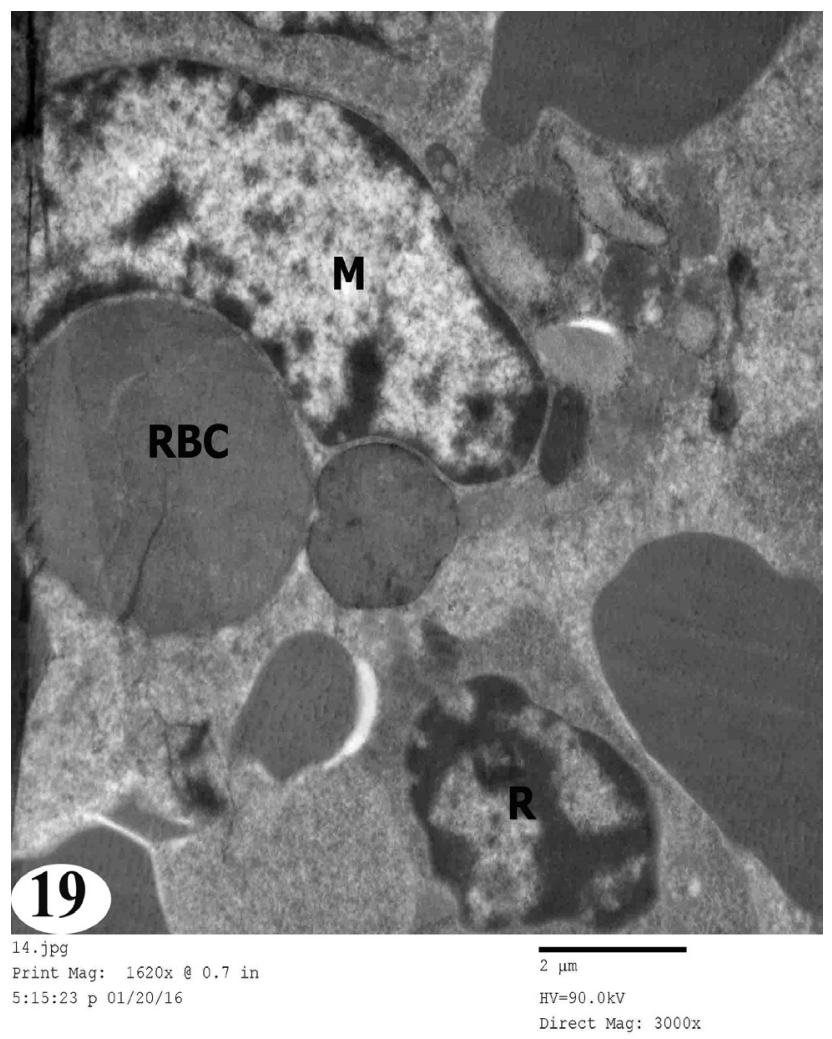

Fig. 19: An electron micrograph of a rat spleen from subgroup IIb showing the cellular components of the red pulp; macrophage (M) engulfing red blood corpuscle (RBC) and a reticular cell (R) also seen.

(TEM, X3000).

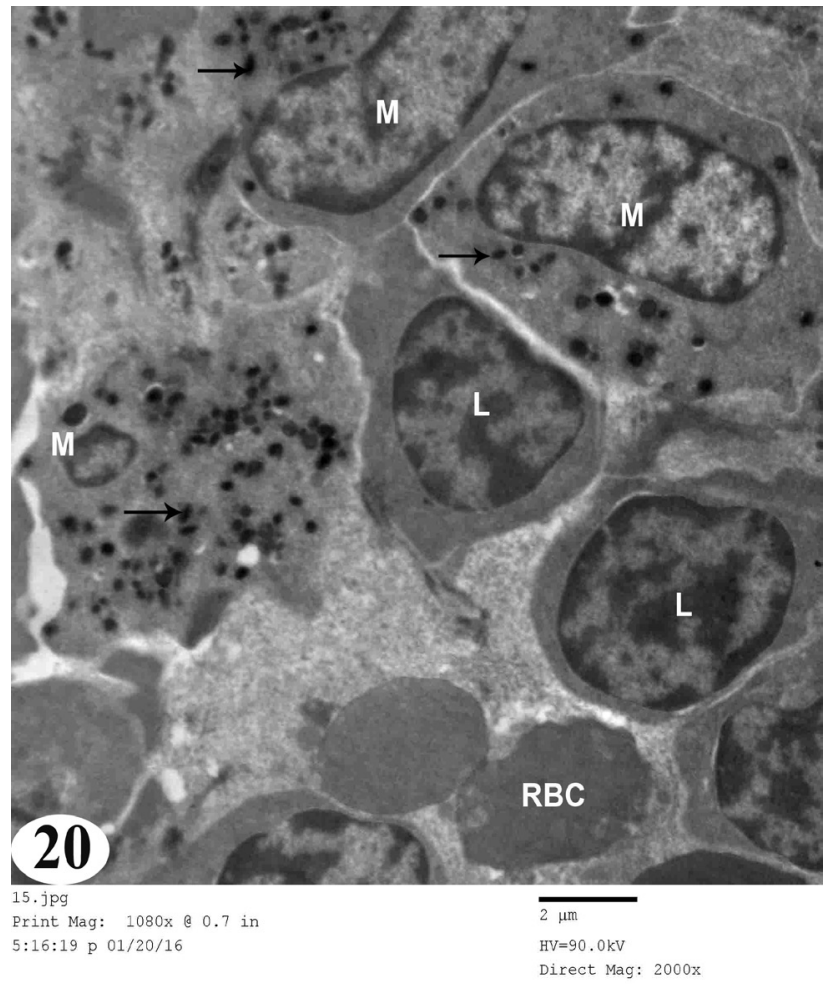

Fig. 20: An electron micrograph of a rat spleen from subgroup IIb showing the cellular components of the red pulp has many macrophages (M) engulfing silver nanoparticles (arrows) and lymphocytes (L) with different grades of condensed chromatin in their nuclei. Red blood corpuscles (RBC) are also seen. (TEM, X2000) 


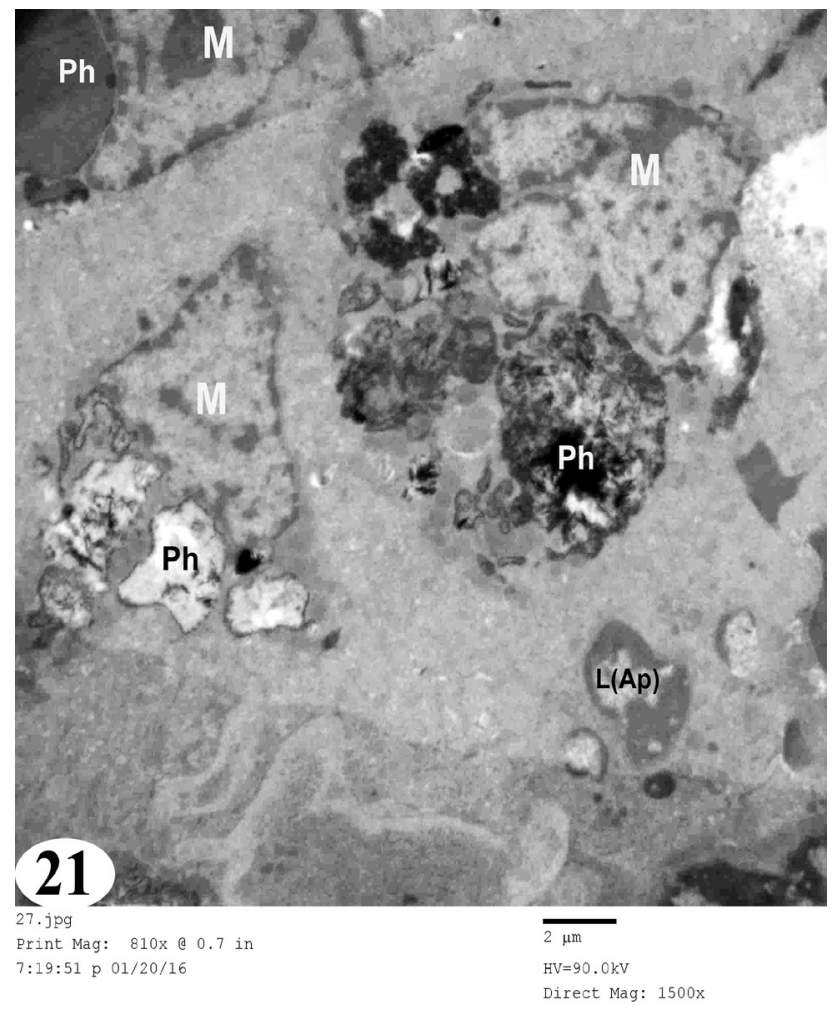

Fig. 21: An electron micrograph of a rat spleen from subgroup IIc showing the cellular components of the white pulp has macrophages $(\mathrm{M})$ containing phagosomes $(\mathrm{Ph})$, and a lymphocyte having nucleus with condensed chromatin in its way to apoptosis $\{\mathrm{L}(\mathrm{Ap})\}$.

(TEM, X1500).

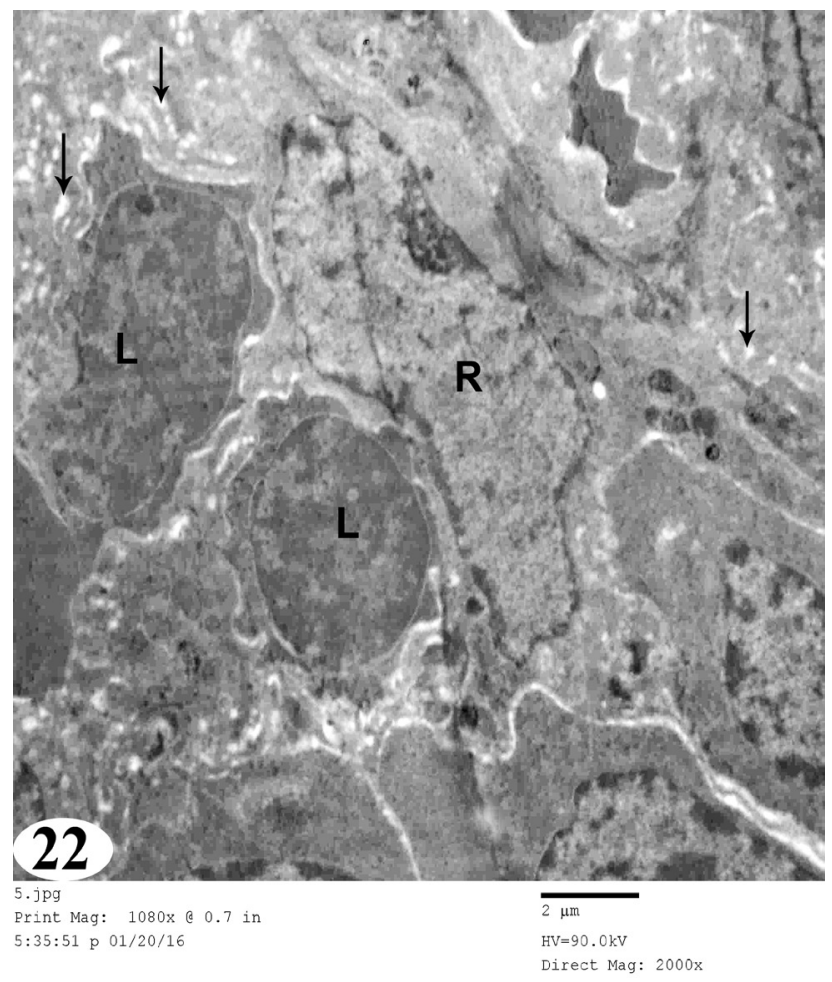

Fig. 22: An electron micrograph of a rat spleen from subgroup IIc showing the cellular components of the white pulp has lymphocytes (L) with dark cytoplasm and reticular cells (R). Most cells have dilated rough endoplasmic reticulum (arrows).

(TEM, X2000).

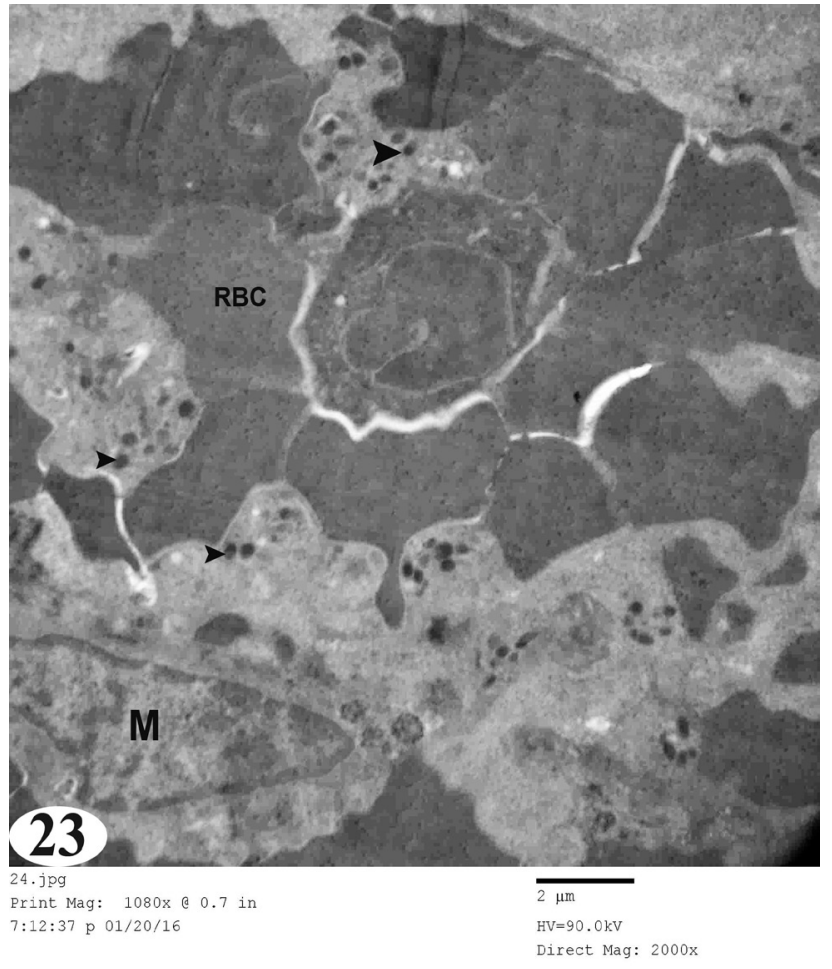

Fig. 23: An electron micrograph of a rat spleen from subgroup IIc showing splenic sinuses with numerous red blood corpuscles (RBC), and macrophages (M) engulfing silver nanoparticles (arrowheads)

(TEM, X2000).

\section{DISCUSSION}

Silver nanoparticles (AgNPs) are presently one of the most frequently used nanomaterials in consumer, industrial and biomedicine application. However, they remain one of the most controversial research areas regarding their distribution, dissolution and their toxicity to biological systems ${ }^{[11]}$. Therefore, the present work investigated the potential toxicity of silver nanoparticles on the structure of rat spleen using different doses, with further assessment of the underlying mechanisms.

There are different routes of administration of AgNPs such as inhalation ${ }^{[20]}$, oral gavage ${ }^{[21]}$, intratracheal instillation ${ }^{[22]}$ and intravenous injection ${ }^{[23]}$. Once nanoparticles enter the body, they may become systemically available regardless the route of administration, thus may cause toxic effects. The oral route should cause less toxicity as compared to the parenteral routes of administration as the bioavailability of nanoparticles would be the least via this route. For nanoparticles of medical applications, their efficacy largely depends on the control of their distribution within the body ${ }^{[24]}$.

Since Yasin et $a l .{ }^{[25]}$ found that spherical, triangular, and hexagonal nanoparticles have better antimicrobial and physical properties if they are produced in a small 
size range, we decided to use uniform, spherical AgNPs, with a particle size of $47-80 \mathrm{~nm}$ that found in aggregates. AgNPs in the $40-50 \mathrm{~nm}$ size range demonstrated the best antimicrobial activity. Once AgNPs aggregate, a significant loss of antibacterial activity occurs due to their inability to penetrate the plasma membrane and loss of surface area (High School Nanoscience Program). Consequently, the decreased stability of AgNPs may lead to loss of their nanoscale properties ${ }^{[26]}$. Further, aggregation of AgNPs decreased their effect and cellular uptake and modifies their bioavailability and toxicity ${ }^{[27]}$. Moreover, Jiang et al. ${ }^{[28]}$ suggested that sonification of the dose for 10 minutes immediately before injection may prevent aggregation of AgNPs before they can be taken up by the systemic circulation. It has been reported that some nanomaterials can activate immunological responses ${ }^{[29]}$. AgNPs can also trigger innate and adaptive inflammatory responses due to oxidation stress $^{[30]}$.

Our data showed histopathological changes in the splenic architecture and splenocytes structure caused by aggregations of AgNPs in spleen parenchyma. These changes were lymphocytes depletion, splenic follicle size reduction, cellular vacuolation, nuclear fragmentation, and accumulation of apoptotic bodies, indicating apoptosis.

Consistent with our results, Lucian et al..$^{[31]}$ reported that nanoparticles-induced tissue damage shows an explicit dose-dependent trend that is, the higher dose showed more severe damage to the spleen of the experimental rats. Austin et al. ${ }^{[32]}$ added that toxicity of AgNPs is time-dependent and that deposition of AgNPs in tissue samples is size-dependent. It has also been demonstrated that different sized and shaped gold nanoparticles have different toxicity ${ }^{[33]}$.

The current work showed accumulation of nanoparticles in both white and red pulps of the spleen. In agreement, $\mathrm{Lam}^{[34]}$ found that silver and silver salts are distributed to the whole body and finally accumulate in the liver, kidney and spleen. In the same context, Loeschner et al. ${ }^{[35]}$ reported that in AgNPs-exposed rats, the silver accumulated in the intestinal tissue is mostly spherical but strongly aggregated electron dense granules were found in the lysosomes of macrophages within the lamina propria, and individual granules in the basal lamina of the epithelium. Furthermore, single granules were found randomly distributed in the connective tissue of the submucosa. These findings were in consistent with our study where macrophages were seen engulfing silver nanoparticles. Singh and Ramarao ${ }^{[36]}$ demonstrated that AgNPs are internalized by macrophages. AgNPs are degraded intracellularly to release Ag ions which interfere with normal mitochondrial functions and induce apoptotic cell death. They suggested that AgNPs are cytotoxic and proinflammatory in nature.

In this study, the vacuolar degeneration observed in the parenchyma of the spleen treated with AgNPs was consistent with Zhang et al. ${ }^{[1]}$ who suggested that AgNPs induced autophagosome formation containing cellular debris, disintegrating material and lipid droplets, and altered intracellular homeostasis and adaptation to stress. Griffiths ${ }^{[37]}$ added that after 24 hours of treatment, AgNPs aggregated in the cytoplasm and appeared as dense inclusions in lysosomes which are the endpoints of ingested material marked for degradation. Li et al. ${ }^{[38]}$ reported that gold nanoparticle-treated fibroblasts exhibit a significant number of vacuoles in the cytoplasm, many of which contained large clusters of these nanoparticles. Our results supported this theory where nanoparticles were seen in both white and red pulps of the spleen using different doses of AgNPs.

Some studies based on actual data from rat models suggested that AgNPs; despite their beneficial effects, may be cytotoxic even at low doses ${ }^{[39]}$. Foldbjerg et al. ${ }^{[40]}$ suggested ROS generation and oxidative stress to be two likely mechanisms of AgNPs toxicity. Via increasing ROS, phospholipid membranes may be attacked, and the function of the mitochondrial respiratory chain complexes decreases ${ }^{[41,42]}$. In agreement, Asharani et al. ${ }^{[43]}$ reported that ROS that was generated in the presence of AgNPs could explain the metabolic disturbances as well as other toxicological outcomes. It is possible that surface oxidation of AgNPs, upon contact with cell culture medium or proteins in the cytoplasm liberates Ag ions that could amplify the toxicity.

Higher concentrations of AgNPs were found to induce genotoxicity, and DNA damage ${ }^{[44,45]}$. Also, AgNPs can induce reduction of cell viability with inhibition of groups of growth factors that led to inhibition of DNA synthesis and cell death ${ }^{[10]}$. This could explain the depletion of lymphocytes of spleen white pulp in rats receiving AgNPs which was increased by increasing the dose. Fadeel et al. ${ }^{[46]}$ found that ROS are known to trigger the apoptotic cascade, via caspases, which are considered as the executioners of apoptosis. In agreement, our study revealed highly statistical significant increase in the mean value of caspase-3 optical density in rats receiving AgNPs when compared to the control group. Noteworthy, caspase- 3 activation results in the DNA fragmentation and is often considered as the point of no return in apoptosis $^{[47]}$.

Megakaryocytes (MK) are the cells responsible for the production of platelets, and this production is determined in part by MK size, number and 
maturation state, as well as the production of several cytokines. Megakaryocytic proliferation may result in increased production of platelets and increased risk for thromboembolic events ${ }^{[48]}$. Megakaryocytes arise from pluripotent hematopoietic stem cells capable of differentiation into all of the cell lines that reside in the bone marrow and produce blood cells. MK differentiation and proliferation are regulated by a number of cytokines. However, thrombopoietin (TPO) is regarded as the primary regulator of MK maturation, including cellular enlargement and nuclear poplyploidisation. Thrombopoietin binding to its receptor; MP1, results in the activation of wide spectra of signalling events that end in maturation, proliferation and an increase in platelets ${ }^{[49]}$. Per our results, the spleen of rats receiving high dose of AgNPs revealed two lineages of hematopoietic elements: erythropoiesis and thrombopoiesis. The latter showed increased frequency of multilobed megakaryocytes indicating extramedullary haemopoiesis. Similarly, Lee et al. ${ }^{[50]}$ reported increased number of megakaryocytes in the spleen of rats after administration of copper nanoparticles.

According to Trickler et al. ${ }^{[51]}$, AgNPs can induce inflammation to microvessel endothelial cells of the blood brain barrier in a dose, time, and size-dependent manner. The responses to AgNPs were demonstrated by the increasing permeability of biological barrier and the reducing integrity of endothelial cell monolayer. This could explain vascular changes that appeared in the group treated with higher doses of AgNPs as widening and congestion of the splenic sinuses. Similar results were detected by Sarhan and Hussein ${ }^{[5]}$.

The findings of our current research have important implications for future practice. Caspase- 3 assays were correlated in direct proportion with the doses of AgNPs i.e. caspase-3 activity increased with the increase in the dose. This finding has a clinical application, as explained by Tian et al..$^{[52]}$ who found that AgNPs could provide a permissive environment that favors scarless wound repair at low doses while at higher doses of AgNPs, necrotic changes are seen. Accordingly, at such doses AgNPs could elicit an inflammatory response which could adversely affect the wound healing process.

\section{CONCLUSION}

AgNPs; frequently used for biomedical application, provoked a dose-dependent structural changes in the spleen of adult male albino rats with evidence of an inflammatory response and oxidative stress.

\section{CONFLICT OF INTEREST}

There are no conflicts of interest.

\section{REFERENCES}

1. Barnes C, Elsaesser A, Arkusz J. Reproducible comet assay of amorphous silica nanoparticles detects no genotoxicity. Nano Lett 2008; 8:3069-3074.

2. Magaye R, Zhao J, Bowman L. Ding, M. Genotoxicity and carcinogenicity of cobalt-, nickel- and copperbased nanoparticles. Exp. Ther. Me 2012; 4:551-561.

3. Robertson TA, Sanchez WY, Roberts MS. Are commercially available nanoparticles safe when applied to the skin? J. Biomed. Nanotechnol 2010; 6:452-468.

4. Reidy B, Haase A, Luch A, Dawson KA, Lynch I. Mechanisms of Silver Nanoparticle Release, Transformation and Toxicity: A Critical Review of Current Knowledge and Recommendations for Future Studies and Applications. Materials 2013; 6: 22952350 .

5. Sarhan OM, Hussein RM. Effects of intraperitoneally injected silver nanoparticles on histological structures and blood parameters in the albino rat. International Journal of Nanomedicine 2014; 9: 1505-1517.

6. Chen X. Schluesener H.J. Nanosilver: A nanoproduct in medical application. Toxicol Lett 2008; 176: 1-12.

7. Ahamed M, AlSalhi MS, Siddiqui MKJ. Silver nanoparticle applications and human health. Clinica Chimica Acta 2010; 411: 1841-1848.

8. Powers CM, Wrench N, Ryde IT, Smith AM, Seidler FJ, Slot-kin TA. Silver impairs neurodevelopment: Studies in PC12 cells. Environ Health Perspect 2010; 118:73-9

9. Galdiero S, Falanga A, Vitiello M, Cantisani M, Marra V, Galdiero M. Silver Nanoparticles as Potential Antiviral Agents. Molecules 2011; 16: 8894-8918.

10. Ahamed M, Siddiqui MA, Akhtar MJ, Ahmad I, Pant $\mathrm{AB}$ and Alhadlaq HA. Genotoxic potential of copper oxide nanoparticles in human lung epithelial cells. Biochem Biophys Res Commun 2010; 396:578-83.

11. Zhang XF, Choi YJ, Han JW, Kim. E, Park JH. Gurunathan S, Kim, JH. Differential nanoreprotoxicity of silver nanoparticles in male somatic cells and spermatogonial stem cells. International Journal of Nanomedicine. 2015; 10: 1335-1357.

12. NIH (National Institute of Health) Guide for the Care and Use of Laboratory Animals, NIH Publication, National Research Council, Bethesda, Md, USA, 1985. P. 85-23. 
13. Kim JS, Kuk E, Yu KN, Kim JH, Jin Park SJ, Lee HJ, Kim SH, Park YK, Park YH, Hwang C, Kim Y, Lee Y, Jeong DH, Cho M. Antimicrobial effects of silver nanoparticles. Nanomedicine 2007; 3: 95-101.

14. Attia, AA. Evaluation of the Testicular Alterations Induced By Silver Nanoparticles in Male Mice: Biochemical, Histological and Ultrastructural Studies 2014; RJPBCS 5(4) 1558-1589.

15. Rahman MF, Wang J, Patterson TA, Saini UT, Robinson BL, Newport GD, Murdock RC, Schlager JJ, Hussain SM, Ali, SF. Expression of genes related to oxidative stress in the mouse brain after exposure to silver-25 nanoparticles. Toxicology Letters 2009; 187 : $15-21$.

16. Bancroft JD, Gamble M. Theory and practice of histological techniques. $6^{\text {th }}$ ed. Churchill Livingstone: Elsevier Limited. 2007; Pp: 694.

17. Glauret A M, Lewis P M. Biological Specimen Preparation for Transmission Electron Microscope 1 ed., vol. 17. Portland Press, London. 1998.

18. Woods A. Stirling J. Electron Microscopy: The preparative techniques. In Bancroft, J. and Gamble, M. (ed): Theory and Practice of Histological Techniques. $5^{\text {th }}$ ed., Churchill Livingston, New York, Edinburgh, London. 2002; Pp: 682-700.

19. Bancroft JD, Gamble M. Theory and Practice of Histological Techniques, $5^{\text {th }}$ ed. Churchill Livingstone, USA. 2002; Pp: 698-699.

20. Sung JH, Ji JH, Park JD, Yoon JU, Kim DS, Jeon KS, Song MY, Jeong J, Han BS, Han JH, Chung YH, Chang HK, Lee JH, Cho. MH, Kelman BJ, Yu IJ. Subchronic inhalation toxicity of silver nanoparticles. Toxicol Sci 2009; 108:452-461.

21. Kim YS, Song MY, Park JD, Song KS, Ryu HR, Chung YH, Chang HK, Lee JH, Oh KH, Kelman BJ, Hwang IK, Yu IJ. Subchronic oral toxicity of silver nanoparticles. Part Fibre Toxicol 2010; 7:20.

22. Park EJ, Choi K, Park K. Induction of inflammatory responses and gene expression by intratracheal instillation of silver nanoparticles in mice. Arch Pharm Res 2011; 34:299-307.

23. Xue Y, Zhang S, Huang Y, Zhang T, Liu X, Hu Y, Zhang Z, Tang M. Acute toxic effects and genderrelated biokinetics of silver nanoparticles following an intravenous injection in mice. J Appl Toxicol 2012; 32:890-899.

24. Fairoze KI. Histological and ultrastructural studies on the testis of rat after treatment with aluminum chloride. Aust J Basic Appl Sci 2007; 1(1):63-72.
25. Yasin S, Liu L and Yao J. Biosynthesis of silver nanoparticles by bamboo leaves extract and their antimicrobial activity. Journal of Fibre Bioengineering and Informatics 2013; 6(1):77-84.

26. Liu W, Zhou Q, Liu J, Fu JJ, Liu S, Jian G. Environmental and biological influences on the stability of silver nanoparticles. Chinese Science Bulletin 2011; 56:2009-2015.

27. Wick $P$, Manser P, Limbach LK, Dettlaff-Weglikowska U, Krumeich F, Roth S, Stark WJ, Bruinink A. The degree and kind of agglomeration affect carbon nanotube cytotoxicity. Toxicol Letters 2007; 168: 121131.

28. Jiang W, Kim BY, Rutka JT, Chan WC. Nanoparticlemediated cellular response is size-dependent. Nat Nanotechnol 2008; 3:145-150.

29. Jang J, Lim DH, Choi IH. The impact of nanomaterials in immune system. Immune Netw 2010; 10:85-91.

30. Yang EJ, Kim S, Kim JS, Choi IH. Inflammasome formation and IL-1 $\beta$ release by human blood monocytes in response to silver nanoparticles. Biomaterials 2012; 33:6858-67.

31. Lucian H, Marius S, Laura U, Anca N, Marius M, Liliana T, Viorel M. Exposure to nanoparticles induces oxidative stress and memory deficits in laboratory rats. Cent Eur J Biol 2011; 6 (4): 497-509.

32. Austin CA, Umbreit TH, Brown KM, et al., Distribution of silver nanoparticles in pregnant mice and developing embryos. Nanotoxicology 2012; 6:912-922.

33. Hillyer JF, Albrecht RM. Gastrointestinal persorption and tissue distribution of differently sized colloidal gold nanoparticles. J Pharm Sci 2001; 90:1927-1936.

34. Lam $\mathrm{CW}$. A review of carbon nanotube toxicity and assessment of potential occupational and environmental health risk. Crit. Rev. Toxicol 2006; 36: 189-217.

35. Loeschner K, Hadrup N, Qvortrup K, Larsen A, Gao X, Vogel U, Mortensen A, Lam HR, Larsen EH. Distribution of silver in rats following 28 days of repeated oral exposure to silver nanoparticles or silver acetate. Particle and Fibre Toxicology 2011; 8-18.

36. Singh, RP, Ramarao P. Cellular uptake, intracellular trafficking and cytotoxicity of silver nanoparticles. Toxicology Letters 2012; 213: 249- 259.

37. Griffiths GM. Gaucher disease: forging a new path to the lysosome. Cell 2007; 131(4):647-649. 
38. Li JJ, Hartono D, Ong CN, Bay BH, Yung LY. Autophagy and oxidative stress associated with gold nanoparticles. Biomaterials 2010; 31(23):5996-6003.

39. Kawata $\mathrm{K}$, Osawa $\mathrm{M}$, Okabe $\mathrm{S}$. In vitro toxicity of silver nanoparticles at noncytotoxic doses to HepG2 human hepatoma cells. Environ Sci Technol 2009; 43:6046-6051.

40. Foldbjerg R, Dang DA, Autrup H. Cytotoxicity and genotoxicity of silver nanoparticles in the human lung cancer cell line, A549. Arch. Toxicol 2011; 85:743750.

41. Costa CS, Ronconi JVV, Daufenbach JF, Gonçalves CL, Rezin GT, Streck EL, da Silva Paula MM. In vitro effects of silver nanoparticles on the mitochondrial respiratory chain. Mol Cell Biochem 2010; 342:51-56.

42. Kim S, Kim S, Lee S, Kwon B, Choi J, Hyun JW, Kim S. Characterization of the effects of silver nanoparticles on liver cells using HR-MAS NMR spectroscopy. Bull Korean Chem Soc 2011; 32:2021-2026.

43. Asharani PV, Mun GK, Hande MP, Valiyaveettil S. Cytotoxicity and genotoxicity of silver nanoparticles in human cells. American Chemical Society, Nano $2009 ; 3: 279-90$.

44. Kim S, Ryu DY. Silver nanoparticle-induced oxidative stress, genotoxicity and apoptosis in cultured cells and animal tissues. Journal of applied toxicology 2012; 33(2): 78-89.

45. Milića M, Leitingerb G, Pavičića I, Avdičevićd MZ, Dobrovićd S, Goesslere W, Vrčeka IV. Cellular uptake and toxicity effects of silver nanoparticles in mammalian kidney cells. J. Appl. Toxicol 2015; 35: 581-592.
46. Fadeel B, Ahlin A, Henter JI, Orrenius S, Hampton MB. Involvement of caspases in neutrophil apoptosis: regulation by reactive oxygen species. Blood 1998; 92, 4808 .

47. Arora, S, Jain, J, Rajwade JM, Paknikar KM. Cellular responses induced by silver nanoparticles: In vitro studies. Toxicology Letters 2008; (179): 93-100.

48. Gonzalez-Villalva A, Fortoul TI, Avila-Costa MR, Piñon-Zarate G, Rodriguez-Lara V, Martinez-Levy G, Rojas-Lemus M, Bizarro-Nevarez P, Diaz-Bech P, Mussali-Galant P, Colin-Barenque L. Thrombocytosis induced in mice after subacute and subchronic V2O5 inhalation. Toxicol Industrial Health 2006; 22: 113116.

49. Lannutti BJ, Minear J, Blake N, Drachman JG Increased megakaryocytopoiesis in Lyn-deficient mice. Oncogene 2006; 25: 3316-3324.

50. Lee IC, Ko JW, Park SH, Lim JO, Shin IS, Moon C, Kim SH, Heo JD, Kim JC. Comparative toxicity and biodistribution of copper nanoparticles and cupric ions in rats. International Journal of Nanomedicine 2016; 11: 2883-2900.

51. Trickler WJ, Lantz SM, Murdock RC, Schrand AM, Robinson BL, Newport GD. Silver nanoparticle induced blood-brain barrier inflammation and increased permeability in primary rat brain microvessel endothelial cells. Toxicol Sci 2010; 118:160-70.

52. Tian J, Wong KKY, Ho CM, Lok CN, Yu WY, Che CM, Chiu JF, Paul KHT. Topical delivery of silver nanoparticles promotes wound healing. Chem. Med. Chem 2007; 2: 129-136. 


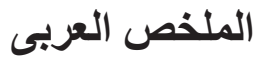

\section{دراسة نسيجية وهنتوكيميائية مناعية عن السمية المحتملة لجزيئات الفضة المتناهية الصغر على تركيب الطحال في ذكور الجرذان البالغة}

نهاد فهمى مازن', ابتهال زيد صالح', عبير عبدالعظيم محمود', علي عبد اللطيف شعلان

قسم الأنسجة وبيولوجيا الخلية ـ كلية الطب - جامعتي الزقازيق' وقناة السويس

المقدمة: لا تزال جزيئات الفضة المتناهية الصغر واحدة من المجالات البحثية المثيرة للجدل بشأن انتشار ها، وانحلالها وسميتها على النظم البيولوجية.

الهـف: در اسة السمية المحتملة لجر عات مختلفة من جزيئات الفضة المتناهية الصغر على تركيب طحال الجرذان. مواد وطرق البحث: تم تقسيم أربعون من ذكور الجرذان البيضاء البالغة إلى مجمو عتين رئيسيتين. المجموعة الضابطة: اشتملت على عشرة جرذان أُعطيت محلول ملحي عن طريق الحقن داخل الغشاء البريتوني،يومياً. المجموعة التجريبية: اشتملت على إنى ثلاثين جرذاً نت حقنهم بجزيئات الفضة المتناهية الصغر (المذاب في محلول ملحي) داخل الغشاء البريتوني، وقسمت بالتساوي إلى الى ثناث مجمو عات فر عية: المجمو عة الفر عية (أ) تم حقنها ( . . ( ملجم/كجم/يوم)، المجموعة الفرعية (ب) تم حقنها ( . .0 ملجم/ كجم/يوم)، المجمو عة الفرعية (ج) وتم حقنها ( ... ملجم/كجم/يوم). بعد ^ץ يوما، تم أخذ عينات الطحال و أعدت للار اسة

$$
\text { بالمجهرين الضوئي والالكتروني. }
$$

النتائج: أظهرت النتائج ان طحال الجرذان المعالجة بجزيئات الفضة المتناهية الصغر به تغيرات تركيبية مرتبطة بالجر عة. وكانت هذه التغيرات عبارة عن نقص في حجم اللب الأبيض مع استنفاذ (نفاد - نضوب) الخلايا اللبمفاوية، وتحللها وموتها. وشوهدت جزيئات الفضة المتناهية الصغر في كل من اللب الأبيض والأحمر للطحال. وقد لوحظ زيادة احصائية فى الكثافة

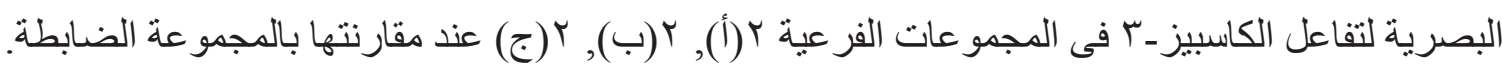
الخلاصة: أحدثت جزيئات الفضة المتناهية الصغر تغير ات تركيبية في الطحال مع التهابات وتوتر تأكسدى. وكانت هذه الآثار مرنبطة بالجر عة. 